\title{
Ficções e interações: as ficções artísticas e a questão do espaço
}

\author{
BERNARD GUELTON
}

TRADUÇÃO de NIKOLETA KERINSKA e BEATRIZ RAUSCHER

Bernard Guelton desenvolve, desde o final dos anos 80, produções artísticas e intervenções que questionam os contextos sociais e arquitetônicos. A questão das relações entre arquitetura e ficção caracteriza parte de suas criações concebidas para atores e lugares especificos. Comprometido com a concepção e curadoria de exposições, além da criação artística pessoal, Guelton já realizou cerca de cinqüenta exposições dentro e fora da França. No contexto acadêmico, Bernard Guelton lidera a linha de pesquisa e Fictions \& interactions (Ficções \& Interações) do Institut Acte da Universidade de Paris 1 Panthéon-Sorbonne. Esta linha de pesquisa tem como objetivo analisar as características da ficção em termos de práticas artísticas e visuais. Sua principal contribuição é confrontar as abordagens realizadas pela teoria literária e filosofia da linguagem da ficção canônica ( literatura e cinema), com as ficções artísticas, raramente estudadas. A linha reúne artistas, filósofos e teóricos literários. Entre as suas principais publicações estão Images et récits (Dir.) L'Harmattan, 2013 ; Fiction et médias, intermédialités dans les fictions artistiques, (Dir.) Publications de la Sorbonne, 2011 ; Les arts visuels, le web et la fiction, (Dir.) Publications de la Sorbonne, 2009 ; Archifiction: quelques rapports entre les arts visuels et la fiction, Publications de la Sorbonne, 2007 ; L'exposition, interprétation et réinterprétation, L'Harmattan, 1998. http://www.fictions-et-interactions.org

http://www.archifiction.org

http://search-site.univ-paris1.fr/index.php?s=bernard + guelton

http://www.institut-acte.cnrs.fr/fictions-interations

Tradução de Nikoleta Kerinska e Beatriz Rauscher a partir do original publicado neste mesmo número. 


\section{RESUMO}

Nessa curta apresentação, vou esboçar algumas questões sobre as relações possíveis entre o espaço e a ficção, depois farei um panorama da evolução da linha de pesquisa Fictions \& Interactions (Ficções \& Interações). Na primeira parte abordarei três questões: 1) a relação entre a ficção e a espacialidade das imagens; 2) os espaços imersivos; e 3) três exemplos de obras artísticas e performativas que põem em jogo a noção de espaço em realidades alternadas.

\section{PALAVRAS-CHAVE}

Ficção, espaço, imersão.

\section{- RÉSUMÉ}

Dans cette courte présentation, je vais esquisser quelques questions sur les rapports possibles entre l'espace et la fiction puis je vais faire un aperçu sur l'évolution de la ligne de recherche Fictions et interactions. Dans la première partie, je vais aborder trois questions : 1) le rapport entre la fiction et l'espace des images, 2) les espaces immersifs et 3) trois exemples d'œuvres artistiques et performatives qui mettent en jeu les espaces en réalités alternées.

\section{- MOTS-CLÉS}

Fiction, espace, immersion.

\section{A questão da ficção e do espaço}

\section{A. 'Ficções'}

Ao nomear esta intervenção Ficções e interações: as ficções artísticas e a questão do espaço, eu esclarecerei a abordagem destas duas noções chaves que são a ficção e o espaço. As definições de ficção pensadas juntamente à noção de espaço, propiciam leituras polissêmicas. Portanto gostaria de traçar uma base teórica, começando pelo termo ficção.

1) Primeiramente farei uma distinção entre ficções artísticas e ficções canônicas. Entendo por ficções canônicas as ficções literárias ou cinematográficas pelas quais a noção de ficção é mais frequentemente aceita. Nas ficções artísticas, a experiência concreta do espaço é fundamental e vem se articular de uma maneira particular com os espaços representados e imaginados.

2) Em segundo lugar reexaminarei as três significações - ou três dimensões - correntemente aceitas por todos os dicionários a respeito do termo ficção: a) a primeira dimensão é a da simulação, da dissimulação e da mentira (a intenção deliberada de enganar é, obviamente, excluída de uma abordagem mais precisa); b) a segunda dimensão do termo ficção é a de uma construção imaginária; c) a terceira concerne o registro da suposição, ou de uma hipótese, que permite a elaboração de um raciocínio'. Resumirei estas três dimensões da ficção por simulação, imaginação e suposição.

3) Por fim de uma maneira mais erudita, apelarei aqui à proposição de Jean-Marie Schaeffer que distingue quatro atratores semânticos que refletem a polissemia e a diversidade do termo ficção: a ilusão, a construção ilusória², a simulação, a

Baseado no Le trésor de la langue française informatisé, disponível em http://atilf.atilf.fr/

2 No original lê-se feintise, proveniente do verbo feindre, que significa aparentar, dissimular, querer passar-se pelo 
moldagem ${ }^{3}$ e o jogo.

Cito: "Cada um dos atratores implica uma visão diferente da ficção: a aproximação com a ilusão a atraí para uma categoria de erro, centrada na ideia de construção ilusória aproxima-se mais da mentira, ligada a ideia de moldagem revela o seu fator de invenção (e por vezes de artifício), finalmente a perspectiva do jogo a coloca em uma ênfase pragmática"4.

4) Várias características são comumente associadas ao termo ficção: narrativa ou relato, mimésis ou ilusão, imersão ou absorção. Trata-se por sua vez de características secundárias, mas não decisivas 5 . Elas, contudo, comprometem as abordagens teóricas da ficção, em primeiro lugar, para esclarecer as diferenças entre cada abordagem do termo ficção, em seguida para determinar a importância da narração, da ilusão e da imersão.

5) Três grandes tipos de abordagens abrangem os estudos sobre a ficção: a) a abordagem semântica ou a dos conteúdos ficcionais; b) a abordagem sintática ou a das formas da ficção (Existem características específicas na narrativa ficcional?); c) a abordagem pragmática ou a dos usos, dos posicionamentos e das interações entre autor e receptor.

\section{B. 'Espaços' e ficção}

\section{Espaço narrativo}

Do ponto de vista das ficções canônicas (literatura, cinema) a questão da narrativa é muito importante. Convém então examinar a questão do espaço desse ponto de vista antes de considerar a questão das imagens e das práticas artísticas contemporâneas. Entre os teóricos tradicionais da narrativa (Ricoeur, Genette), a abordagem do espaço narrativo está concentrada quase sempre sobre a temporalidade negligenciando a questão do próprio espaço (exceto para considerar a noção de espaço narrativo de uma maneira metafórica, voltada a designar o espaço dos atores, dos modos narrativos e do sequenciamento da história como 'espaço narrativo'). Estas abordagens estão mudando e o espaço se torna um objeto de investigação em narratologia.

Cito Marie-Laure Ryan: "Enquanto o espaço foi minimizado nas teorias que consideraram a narração como arte do tempo, agora é cada vez mais objeto de atenção como algo mais do que apenas um pano de fundo para a trama".

Atualmente os teóricos colocam em evidência o papel crítico desempenhado nos vários tipos de narração. Isto é especialmente perceptível para as narrativas digitais, cibernéticas e virtuais contemporâneas nas quais o tempo e espaço desempenham funções complementares, senão de igual importância. Os novos estudos de nomes de lugares, as politicas de nomes de localidades, as controvérsias a propósito de textos inscritos na paisagem, todos estes elementos destacam as conexões entre os mundos vividos e os mundos textuais ${ }^{6}$. Nosso projeto vai além de um simples

que não é. O termo feintise é utilizado por Jean-Marie Schaeffer na definição do conceito de ficção, que contempla a expressão feintise ludique partagée, (in Pourquoi la fiction?, Éd. Seuil, Paris, 1999). Feintise designa, portanto, as construções ilusórias, tendo uma relação direta com o conceito de ficção (N. do T.).

3 No original lê-se façonnage, indicando a ideia da concepção de uma forma (N. do T.).

4 J.-M. Schaeffer, "Quelles vérités pour quelles fictions?", in Vérités de la fiction. Éd. L'Homme, 2005, p. 20.

5 Podemos agregar também a noção de contrato que é uma abordagem pragmática da ficção.

6 Marie-Laure Ryan. Space, place and story: Toward a spatial theory of narrative, Projeto de publicação coletiva, 
estudo sintético sobre as pesquisas recentes (...) fazendo convergir quatro aspectos: 1) o espaço representado pela narrativa numa variedade de níveis e de escalas, 2) as referencias espaciais do texto que são as descrições, as representações ou implicações do espaço real na narrativa, seja o conteúdo referente a determinadas localidades, 3) a forma espacial do texto, 4) o espaço como contexto e conteúdo do texto.

O conjunto dessas observações permite considerar o espaço no centro de interesses das preocupações artísticas, desde sempre. Como esta segunda noção não poderia ser mais extensa e problemática, irei abordá-la do ponto de vista das práticas artísticas indo do simples ao complexo, ou, melhor, das imagens bidimensionais até as práticas performativas em realidades mistas.

\section{Espaços de imagens}

a) O problema da ficcionalidade das imagens

A questão da ficcionalidade das imagens não é consenso, e é amplamente debatida. Se o trabalho de Kendall Walton (Mimesis as Make-beleive) é uma tentativa de definir a ficção como representação na arte, ou seja, para determinar o que é comum entre as obras: Uma Tarde de Domingo na Ilha de Grande Jatte ( Un dimanche après-midi à l'Île de la Grande Jatte) de Seurat, Um conto de duas cidades (A Tale of Two Cities) de Dickens, Intriga Internacional (North by Northwest) de Hitchcock, A Flauta mágica (Die Zauberflöte) de Mozart, e David de Michelangelo (...). Muitos autores recusaram uma concepção tão ampla da noção de ficção. Lorenzo Menoud no livro Qu'est-ce que la fiction? insiste que a ficção não poderia ser constituinte à fotografia, nem à pintura e menos ainda à escultura, porque esses meios não tem a capacidade de se desenvolver de maneira 'discursiva'. Marie-Laure Ryan por sua vez, argumenta que todas as mídias apresentam uma zona de indeterminação. A importância dessa zona varia em função do suporte, proporcional à capacidade do meio na construção de verdades precisas e de narrar histórias. A linguagem verbal tem esta capacidade de transmitir informações precisas numa forma de narrativa, o que não faz uma imagem pintada, desenhada ou fotografada, que deixa ao espectador uma grande amplitude de pontos de vista e de interpretações. As imagens desafiam a teoria da ficcionalidade porque elas são incapazes de enunciar proposições de forma inequívoca, como observou Sol Worth $(1981)^{7}$. Jean-Marie Schaeffer desenvolve uma pro-

2011. Em uma abordagem mais precisa, Marie-Laure Ryan define o espaço narrativo como "o ambiente físico existente no qual vivem e se deslocam os personagens" (BUCHHOZ \& JAHN, 2005). Ela distingue: a) o contexto espacial: ambiente imediato de eventos reais, os diferentes lugares empregados nos discursos narrativos ou para a representação (Ronen, 1986), b) o contexto: o ambiente sócio-histórico-geográfico no qual a ação se desenrola, c) o espaço da história: o espaço que abrange a trama, mapeamento das ações e dos personagens, d) o mundo narrativo (ou a história): o espaço da história completado pela imaginação do leitor sobre a base de seu saber cultural e de sua experiência real do mundo (Ryan, 1991), e enfim e) o universo narrativo: o mundo (entendido no sentido espaço-temporal do termo) apresentado como real no texto, no qual se acrescenta mais mundos contrafactuais desenvolvidos por figuras como crenças, esperanças, medos, especulações, reflexão hipotética, sonhos e fantasias.

7 Consideremos esta frase: "O gato está sobre a almofada." Ela tem um argumento claro: o gato. Graças ao artigo definido, ela capta um referente especifico: esse gato, não outro. Seu predicado nos diz que é uma questão da propriedade específica do gato: estar numa almofada. Não há raça, cor, ou posição exata sobre a almofada. A mensagem de uma imagem representando um gato sobre uma almofada é muito mais embaraçada. $O$ espetador com certeza identificará a imagem como representação de um gato, mas no lugar de refletir sobre o fato de que o gato está sobre a almofada, ele pode fixar sua atenção sobre os olhos verdes do gato, sobre sua espessa pelagem, sobre seu olhar para o fotógrafo, etc. 
posta mais rica e mais sutil, assumindo que certos tipos de imagens, tais como a pintura, podem revelar modos ficcionais.

\title{
b) Espaço plano e a representação ilusionista de um espaço
}

O debate sobre a ficcionalidade das imagens pode se engajar de forma diferente do que a sua relação com o universo da linguagem. É a princípio a abordagem filosófica que serve de ponto de apoio. Assim, o que é o espaço plano das imagens? Como um suporte bidimensional pode gerar uma representação, ou um espaço tridimensional? Essas questões, resumidamente, desdobram-se a partir das posições de Ernst H. Gombrich sobre a percepção ilusionista das imagens e de Richard Wollheim sobre a dupla percepção. Vejamos uma citação de Ernst H. Gombrich que considera o problema de exemplos de imagens ambíguas que podem ser interpretadas de várias maneiras:

\begin{abstract}
"Mais que a flexibilidade e o caráter revogável da representação, o que é interessante reter dessas experiências, é o aspecto exclusivo de interpretação $[. . .]^{8}$. Nós não temos nenhuma consciência de uma apresentação ambígua; simplesmente nós nos entregamos a diferentes interpretações. É a 'substituição' de uma interpretação por outra que nos permite perceber que, sobre o mesmo contorno, podem ser projetadas diferentes formas. Nós podemos nos treinar a passar mais rapidamente de uma interpretação à outra, nos podemos também hesitar entre diferentes projeções possíveis, mas nós não podemos nos adaptar simultaneamente a dois tipos de interpretação"'.
\end{abstract}

Richard Wollheim:

"Olhando para uma superfície devidamente marcada, estamos visualmente conscientes ao mesmo tempo da superfície marcada e de algo que está à frente ou atrás de qualquer outra coisa. Chamo este recurso da fenomenologia de 'dupla percepção'. Meu plano inicialmente era definir uma oposição à concepção de Gombrich - que postula duas percepções alternadas, às vezes tela, às vezes natureza, sobre o modelo de analogia enganadora de às vezes pato, às vezes coelho - assim, identifiquei a dupla percepção como duas percepções simultâneas: uma da superfície da imagem, outra daquilo que ela representa. Mais recentemente, analisei a dupla percepção e agora eu entendo que temos uma única experiência que comporta dois aspectos que chamei de configuracional e recognitivo" ${ }^{10}$.

Segundo Anne Reboul, estudos recentes em cognição tendem a fornecer bases neurológicas convergentes mais com a teoria de Wollheim do que a de Gombrich. Compreendemos que este debate inscreve-se numa perspectiva da compreensão da dimensão ilusionista das imagens, que pode participar parcialmente do debate sobre o caráter ficcional das imagens. A ilusão pode fornecer segundo Montalbetti ${ }^{11}$ um paradigma para a imersão ficcional (que abordaremos mais adiante), e nesse sentido a ficção funcionará em relação ao modo de ilusão de ótica. Na ilusão de ótica, eu reconheço que mesmo

8 [é fácil de enxergar nesse óculo um rosto visto de frente, ou uma abotoadura, ou ainda uma letra, mas é difícil - na verdade, impossível - ver tudo isso ao mesmo tempo.]

9 Ernst H. Gombrich, L'art et l'illusion (1960). Editions Gallimard, 1987. p. 296.

10 Richard Wollheim. "La représentation iconique", in Esthétique contemporaine, art, représentation et fiction, Textes réunis par J.- P. Cometti, J. Morizot, R. Pouivet, Éd. Vrin, 2005, p. 234.

11 Christine Montalbetti. La fiction, Éd. GF Flammarion, 2001. p. 229. 
sendo enganado, mantenho minha 'falsa' percepção ativa. Mas para que a ilusão pudesse funcionar plenamente, no sentido comum da ficção, Ihe falta uma dimensão temporal construída como tal (e não uma mera temporalidade do sistema perceptivo). No entanto, sem ver nessa dimensão temporal uma necessidade, Jean-Marie Schaeffer toma o exemplo de uma imagem do Unicórnio (produzida por um artista que não acredita nos unicórnios, para um espectador que sabe que unicórnios não existem...) como um exemplo simples e incontornável de uma imagem ficcional.

\section{c) Espaço sequencial}

Diferentemente de uma imagem única, uma grande parte dos teóricos que se concentram sobre a ficção reconhecem, em uma série de imagens fixas sucessivas, a possibilidade de construir uma ficção. Aqui encontramos a situação clássica dos quadrinhos, e de maneira mais problemática, os afrescos representando personagens em uma série de ações, ou, ainda quadros que decompõe no espaço diferentes momentos de um acontecimento. Por exemplo, o personagem de Cristo pode ser encontrado repetido em lugares distintos do quadro a cada etapa importante de sua vida ou da sua Paixão. A constituição de um espaço sequencial pode, portanto tomar diferentes aspectos isolando clara e distintamente várias imagens sucessivas, mas também colocando em cena num só quadro um evento produzindo uma série de atitudes e de efeitos sobre diferentes personagens nas partes distintas do quadro. (Ver por exemplo: Homme tué par un serpent (Paisagem com homem morto por uma serpente) de Nicolas Poussin). Assim, uma pintura de Poussin pode representar um evento sem recorrer a uma sucessão de imagens isoladas, mas por meio da articulação de várias ações em diferentes partes do quadro que se assemelham a uma cena teatral.

d) Espaço cinematográfico

Se há um outro meio, que não a linguagem, pela qual a distinção entre ficção e não-ficção é unanimemente considerada pertinente tanto por teóricos como pelo grande público, esse meio é o cinema. A relevância dessa distinção vem do fato que o cinema pode ser usado para transmitir verdades sobre o mundo real. Em um filme documentário, a câmera registra dois tipos de acontecimentos: primeiramente os acontecimentos do mundo independente de sua captação, por exemplo, os esforços de resgate após um terremoto, e em segundo lugar, os eventos encenados para a câmera, no qual as pessoas realizam ação real ou falam em seu próprio nome, sem representar um papel. O filme de ficção grava eventos simulados sem referencias no mundo real, ou seja, a ação dos atores, e solicita ao espectador considerá-los como personagens que representam ${ }^{12}$.

O cinema e as sequencias de imagens têm a capacidade de transmitir informações factuais sob uma forma de narrativa próxima à linguagem. A distinção entre ficção e não-ficção é então pertinente. O grande público reconhece o cinema como suporte que pode testemunhar um acontecimento real, ou, ao contrário, encenar situações imaginárias, ou seja, formas ficcionais.

Na sua acepção tradicional, o significado primário do espaço fílmico, é "uma

\footnotetext{
12 Marie-Laure Ryan, "Fiction, cognition et médias non-verbaux", in Bernard Guelton (dir.). Fictions \& médias, intermédialités dans les fictions artistiques. Éd. Publications de la Sorbonne, 2011, p. 20.
} 
imagem unitária, plana e enquadrada, que produz uma ilusão de profundidade, e que é constituída de campo e de fora de campo"13. No entanto é difícil não considerar duas características fundamentais que são a montagem de planos descontínuos e a articulação de som e imagem. Estes são os esquemas mais gerais que constituem

de modo amplo o espaço do filme. É o artifício das situações, das ações e dos personagens no interior desse espaço cinematográfico que o qualifica como ficção. Mais é claro que esses elementos de construção do filme são suscetíveis de produzir no espectador um potente sentimento de imersão como darei agora diferentes exemplos.

\section{Espaços imersivos}

Se há uma noção que implica especificamente o espaço, é a da imersão: é a totalidade do individuo que está imerso num ambiente físico e/ou mental. A insistência sobre este conceito e os três exemplos analisados introduzirão o panorama que desencadeará as atividades da linha de pesquisa Fictions et Interactions.

O que queremos dizer por imersão?

A imersão pode ser concebida como um efeito de presença intensiva e variável, física e/ou mental e/ou emocional produzida em situação real ou em situação de apreensão de uma representação, realista ou ilusória (artística ou não artística). As percepções e as consciências visual, auditiva, sinestésica, constituem modalidades diferentes e complementares ao mesmo tempo, em que produzem um sentimento de absorção física, mental e emocional. A imersão é uma situação altamente espacial, de um mergulho do sujeito num ambiente físico e mental.

Considerarei três situações imersivas: real, virtual, ficcional. Se as imersões virtuais e ficcionais são objetos de numerosos estudos, a imersão em situação real fica um tanto incerta, nisso que ela supostamente contempla. Admite-se, portanto de maneira geral, que estar envolvido numa situação urbana ou numa paisagem, ou sentir profundamente uma emoção, são experiências que caracterizam a imersão em situações reais. O termo de realidade alternada utilizado habitualmente no contexto do jogo abarcará esses três domínios em suas associações ou divergências. Tratando-se da arte e do jogo, a ficção será considerada numa acepção restritiva segundo a definição J.-M. Schaeffer (1999): construção ilusória lúdica compartilhada. 'Virtual' terá sentido geral de potencial atualizável (Levy, 1998), mas também nos contextos tecnológicos e digitais, pode ser associado à simulação numérica e à tele-presença.

\section{Imersão ficcional}

Em condições normais da projeção de filmes, todos podem observar (...) que os espectadores na saída, brutalmente lançados do ventre escuro da sala numa luz viva e desagradável do hall, têm às vezes, no rosto um ar confuso (feliz ou infeliz) daqueles que acabam de acordar. Sair de um cinema é um pouco como despertar: nem sempre fácil (exceto se o filme for realmente indiferente) ${ }^{14}$.

\footnotetext{
13 Jacques Aumont, Alain Bergala, Michel Marié, Marc Vernet, Esthétique du film, Éd. Nathan Université, Paris, 1993.

${ }^{14}$ Christian Metz., Le signifiant imaginaire : psychanalyse et cinéma. UGE, coll. «10/18», 1977, p. 143, apud. J.-M. Schaeffer. Pourquoi la fiction, op. cit., p.180, a propósito da "inversão das relações hierárquicas entre a percepção (e a atenção de maneira geral) e a atividade imaginativa".
} 
"Imersão requer fluidez, completude e um espaço-tempo continuo que se desenvolve lentamente, enquanto o corpo imaginário se desenrola no mundo ficcional"15.

Se a primeira citação marca a ruptura abrupta no modo de absorção ficcional, com o retorno à 'vida normal', a segunda evoca uma concepção de imersão ficcional fluída, completa e contínua. O filme é um dispositivo particularmente eficaz para provocar uma inversão da relação entre a atividade imaginativa e a percepção do mundo comum em benefício quase exclusivamente da primeira. Esta inversão é bem menos marcante na absorção literária, que coloca a ficção numa relação de coexistência ou de sobreposição entre dois mundos. $\mathrm{O}$ contexto do jogo em realidades alternadas modifica consideravelmente esse modo de absorção ficcional, colocando em concorrência direta a percepção do mundo comum, agora multiplicado por ferramentas virtuais.

Quatro características de imersão ficcional são propostas por Schaeffer ${ }^{16:} 1$ ) Estado de ativação imaginativa que inverte a relação habitual entre imaginação e percepção, 2) Estado de cisão com coexistência e interpenetração de dois mundos, 3) Estado dinâmico retroativo, 4) Estado de investimento emocional. Esses estados típicos das ficções canônicas são reconsiderados de maneira muito importante nos jogos em realidades alternadas ${ }^{17}$.

\section{Imersão virtual}

Existem três níveis de interação e imersão nos universos virtuais. Philippe Fuchs (1999) propõe uma arquitetura hierárquica fundada sobre uma abordagem antropocêntrica. O modelo se inscreve num enfoque cognitivo e comporta três níveis: 1) Nível das interfaces sensório-motoras que produzem a ligação com o mundo físico, nível qualificado como "imersão e interação sensório-motora"; 2) Nível mental, que corresponde ao pensamento do operador, através de esquemas adquiridos em situações reais, e que ele usa para interagir no mundo virtual; 3) Nível da tarefa ou função a ser executada, caracterizado pela expressão, imersão e interação funcional ${ }^{18}$. Assim, a importância das interfaces sensório-motoras e a importância da tarefa ou função, a serem realizadas, são duas características fundamentais que distinguem claramente a imersão virtual da imersão ficcional, quando essas duas modalidades são combinadas. Pelo contrário, o nível mental é comum a ambos os tipos de imersão.

\section{Imersão em situação real}

A imersão em situação real adquire um sentido mais incerto que a imersão em situação virtual ou ficcional. No entanto, admite-se, que estar envolvido numa situação urbana ou numa paisagem, ou sentir uma emoção, são experiências observadas em todas as imersões em situações reais. Em situação de imersão real, a ativação

15 M.-L. Ryan. Narrative as virtual reality, Johns Hopkins University Press, Baltimore, 2001, p. 352. ["Immersion wants fluidity, wholeness, and a space-time continuum that unfolds smoothly as the imaginary body moves around the fictional world."]

16 J.-M. Schaeffer. Pourquoi la fiction?,op. cit., pp. 179-198.

17 Ver B. Guelton, "Représentations de soi et immersions dans les réalités alternées, dispositifs ludiques et fictionnels", In Interfaces numériques, VOL 1/2 - 2012, p. 287-303, disponível em http://rin.revuesonline.com/article. jsp?articleld $=17703$

18 Alain Grumbach. Cognition virtuelle: réflexion sur le virtuel, ses implications cognitives, ses réalisations artistiques. GET / ENST, Paris, 2004, disponível em http://charles.letaillieur.free.fr/Briques/REV/covi-courte.pdf 
da atenção do sujeito é produzida diretamente pelo seu ambiente. Percepção e ação estão intimamente correlacionadas. Se há o recurso a representações, elas pertencem ao sujeito, não são construídas por outros. Totalmente diferentes são as situações de imersão ficcional e de imersão virtual produzidas usando atrativos ilusórios e artefatos. Nos dois casos, há imersão mimética. Ela repousa sobre a capacidade de 'levar em conta uma coisa como fosse' outra coisa, que não é evidentemente o caso em situação real. A construção ilusória lúdica compartilhada (enquanto atividade construída e orientada do sujeito) permite distinguir a situação de imersão ficcional da imersão real, ou enganosa. Na imersão ficcional tradicional, a relação com o espaço é cindida: o espaço real circundante ainda existe, mas é neutralizado em favor dos espaços imaginados pelo leitor ou espectador. Na imersão virtual, as interfaces sensório-motoras são determinantes, constituindo juntamente com os espaços mental e da tarefa a ser realizada, três 'espaços' em interação, aos quais deve ser acrescentado o quadro físico circundante onde se desdobra a imersão virtual. A imersão em situação real como podemos ver, não deixa de ter algumas dificuldades de definição. Nesse terceiro caso, ou o corpo e as ações do sujeito estão imersos ou englobados pelo espaço físico, não mediado ou representado, ou uma situação emocional, igualmente não mediada ou representada, ocupa a quase totalidade da consciência do sujeito.

\section{Imersão em realidades alternadas}

A imersão em situação real determina o ponto de vista privilegiado para considerar as realidades alternadas. É a partir de uma situação real que se considera prioritariamente uma situação virtual ou uma situação ficcional, enquanto passagens, associações ou transferências de uma situação virtual a uma situação ficcional (ou vice-versa) são mais complexas. No domínio do vídeo-lúdico, por exemplo, a combinação de universos virtuais e ficcionais é mais frequentemente produzida pela inclusão de uma situação ficcional no seio de um dispositivo virtual. No exemplo $A$ Machine to See With, do coletivo de artistas Blast Theory, as imersões e as tensões entre esses três universos estão presentes e potentes, e podem ser descritos sob a forma de encaixes recíprocos.

A imersão em realidades alternadas determina uma questão essencial. Ela pode ser considerada de duas maneiras contraditórias ou complementares: 1) Ou consideramos a passagem de uma 'realidade' para o outra, de uma imersão para outra contra-imersiva; 2) Ou consideramos que há uma absorção própria a essas passagens que é ela mesma imersiva. Contudo, as modalidades de entradas e saídas entre situação imersiva e situação não imersiva também devem ser consideradas para cada um dos modos de imersão. O espaço nas realidades alternadas junta diferentes espaços em situações de 'fricção', de complementaridade, de inclusões ou de exclusões reciprocas.

\section{a) Can You See Me Now?}

Em Can You See Me Now? as realidades alternadas são compreendidas através da experiência de uma corrida entre dois grupos de jogadores: os corredores da cidade e os jogadores on-line localizados em qualquer parte do mundo. Os corredores na cidade devem identificar e localizar os jogadores on-line através de uma representação sintética da cidade. Por meio de seus avatares e suas localizações de GPS, os jogadores são localizados tanto cidade real quanto na cidade simulada. As trocas de áudio entre os 
corredores são também restituídas on-line. Elas permitem perceber as trocas entre os corredores, as barreiras físicas e corporais encontrados nas ruas da cidade, para "pegar" os jogadores on-line.

As mobilizações e as mediações dos objetos técnicos entre os jogadores são múltiplos (computadores on-line, smartfones, sensores GPS, simulações da cidade, walk talks). Elas redefinem de maneira mais ou menos estável as identidades físicas, espaciais, individuais, coletivas, performativas, e lúdicas dos jogadores. Para os membros do grupo Blast Theory, a performance se inscreve igualmente em uma reflexão sobre os desenvolvimentos da telefonia móvel, a recomposição do privado e do público, a memória, as ideias de ausência e de presença. Quando um jogador entra no jogo, ele deve responder a pergunta:

Existe alguém que você não vê há muito tempo e em quem você ainda pensa? Essa pessoa - ausente no espaço e no tempo - parece sem relação com a sequencia do jogo, exceto quando o jogador é pego ou visto por um corredor, e ouve o nome mencionado em seu dispositivo de áudio ${ }^{19}$.

Diferente do segundo exemplo que se seguirá, o caráter coletivo e competitivo do jogo é fundamental. A oposição entre os jogadores on-line e os corredores nas ruas são igualmente determinantes. Os corredores nas ruas são muito envolvidos fisicamente e expostos aos riscos de se deslocar em uma cidade real com seus obstáculos, enquanto os jogadores on-line se deslocam simplesmente com a ajuda de mouse ou teclado. A essas características espaciais muito importantes, soma-se a proliferação de ferramentas e de mediações técnicas. Enfim, o caráter ficcional do jogo está claramente ausente, enquanto no segundo exemplo, a existência ou não de um acordo de construção ilusória lúdica compartilhada ${ }^{20}$ que está no centro do questionamento e envolve o participante.

\section{b) A Machine to See With}

Em 2010, o grupo Blast Theory realiza o projeto A Machine to See With ${ }^{21}$. Esta obra resulta de um procedimento automático, que encontra-se no centro de seu dispositivo. A obra tem um caráter maquínico e cinematográfico; seus elementos constitutivos são os seguintes: um passeio na cidade, um celular, um callcenter automatizado que orienta os jogadores, câmeras filmando seus deslocamentos. Constitui-se, portanto de uma situação lúdica e ficcional, em que o participante é a parte ativa do jogo.

Blast Theory:

A Machine to See With é uma maquina de visão cinematográfica - a trata-se de cinema. Os artistas concebem a cidade como se fosse um espaço cinematográfico, e examinam de que maneira uma quantidade de telas pode ser inserida e deslocada pelas ruas. Sua abordagem é pensar nossos olhos como as próprias telas. Você está num filme, desempenhando o papel principal.

Mas esse papel principal, como veremos, é ambivalente. Você está no centro do dispo-

\footnotetext{
${ }^{19}$ Blast Theory, projeto Can You See Me Now? disponível em http://www.blasttheory.co.uk/bt/work_cysmn.html, e http://www.blasttheory.co.uk/bt/mov/mov_cysmn_tokyo.html

${ }^{20}$ No original lê-se feintise ludique partagée; ver nota 2 (N. do T.).

${ }^{21}$ Blast Theory. A Machine to See With, disponível em http://www.blasttheory.co.uk/bt/work_amachinetoseewith.html
} 
sitivo, mas ao mesmo tempo você opera no seu limite, quase fora dele. Essa situação é possível devido a um conjunto de aparelhos - um dispositivo em última análise todo -poderoso, - que coloca o sujeito como ator principal, ao mesmo tempo negando esse posicionamento essencial. Apresentarei essa ambiguidade usando a narrativa de um jogador. Você é o herói e ator de seu próprio filme, ou apenas uma parte do dispositivo, um acessório de conexão? Quem decide suas ações? É você, o autor de seu próprio filme, organizando todas suas ações, como anuncia o grupo Blast Theory? Ou você é apenas um figurante? Uma simples peça do quebra-cabeça?

Mas, há ainda mais um dado importante: seu papel, principal ou secundário, não é isento de riscos, pois você joga 'de verdade', e certas situações permanecem imprevisíveis. Você joga numa cidade real. Você deve encontrar parceiros ou cúmplices, que você nunca viu, ir a lugares desconhecidos para esconder-se, aproximarse a um banco de verdade... Quem faz parte do jogo e quem está fora? O famoso círculo mágico de Huizinga ${ }^{22}$ tem neste caso um contorno grande e incerto, mas também detém os limites entre os aspectos reais e ficcionais do jogo. Tomaremos a narrativa de Kyle Buchanan que concretiza essas perguntas.

"Como uma exposição multimídia pode transformar um blogger em assaltante de bancos"23

Kyle BUCHANAN

Enquanto atravesso o hall do banco com passos apressados, sinto uma súbita onda de adrenalina. O lugar é tranquilo e há algo que tenho que fazer, alguém que eu deveria encontrar. Estou à procura de uma jovem loira com botas forradas de pele, uma mulher que conheci, mas cujo nome não sei de proposito. Certamente, não estou a espera desse sujeito careca com óculos de sol, que acaba de entrar. "Está funcionando?", pergunta ele, apontando para o caixa eletrônico. Murmuro que eu não sei, percebendo em seguida o quanto isso pode parecer estranho. De repente improviso: "Só estou esperando um amigo, e como está frio lá fora, resolvi esperar aqui." Ele balança a cabeça, sorrindo, mas observa com precisão: "O sol apareceu novamente. Legal!" Neste momento me pergunto se ele sabe que, estou prestes a assaltar o banco. E, se ele souber, será que ele entende que Sundance me pediu isto? ${ }^{24}$

Será que esse homem, com seu telefone, que apareceu uns minutos atrás, também

\footnotetext{
22 Trata-se da teoria do circulo magico formulada por Johan Huizinga no seu livro Homo Ludens (1938).

${ }_{23}$ Depoimento disponível em: http://nymag.com/daily/entertainment/2011/01/how_i_tried_to_rob_a_bank_toda.html

24 [...] Blast Theory Duas horas mais cedo, saindo da exposição, recebi um telefonema. $\hat{E}$ uma mensagem gravada, lenta e perturbadora: "Ligue para este número para receber instruções." Eu ligo, disseram-me de seguir algumas ruas em direção a um quartel de bombeiros. Se eu perder uma instrução, disse a voz, qualquer uma, durante a primeira hora, o jogo está perdido. Eu ando pelas ruas, e teclo "um" para confirmar que aceitei as regras do jogo, e a voz me diz que as câmeras estão fixas em mim. Eu rio, mas olho ao redor. Há câmeras de vigilância na sala de Blast Theory... Será que elas realmente estão me vigiando, gravando minhas ações? Disseram-me que a minha missão é roubar um banco em Park City. Eu sorrio. Os caras de Blast Theory disseram ainda que algumas pessoas ficam com medo sabendo o objetivo da missão, mas eu estou determinado a fazer tudo o que será mandando. Afinal de contas, eles não vão me pedir para realmente roubar um banco, não é? [...] "Vire à esquerda e desça a rua," ordenou a voz. "Tenta não parecer suspeito." Obviamente, é difícil agir normalmente, na medida em que a voz descreve adequadamente as coisas ao meu redor, incluindo os edifícios e os frisos das janelas. A voz começa me testar, fazendo perguntas, me diz para ignorar os belos lugares do parque, para prestar atenção nas pranchas de madeira que sustentam as janelas das casas abandonadas. Às vezes eu quebro suas ordens. Eu ignoro o que me perturba, por certo esses testes não devem me colocar em risco de fato.
} 
faz parte do jogo? O que pensar dessas duas mulheres que sorriram para mim quando passei perto delas? Na medida em que a voz me pede para fazer coisas cada vez mais estranhas e contestáveis, é possível que todas as consequências façam parte do plano? Finalmente, eu estou em frente do caixa eletrônico, dois pensamentos me vêm em mente: os limites indicados pela voz sobre o assalto do banco, e alerta que, em caso eventual de intervenção da policia, eles não se responsabilizam pelas consequências. Enquanto o cara simpático está mexendo no teclado do caixa eletrônico, a voz me diz de mudar de plano. Agora, tenho que ir. Esqueço o cara simpático, que invadiu meu espaço. "Você precisa ir a algum lugar?", pergunta ele. Proposta inocente ou elemento do jogo? Eu nego, enquanto a voz me diz que precisa de mim dentro do banco em 10 segundos. Já começou a contagem regressiva pelo fone de ouvido. "9 ... 8 ..." será que este é o momento que devo recuar? "7 ... 6 ..." será que nesse momento tem alguém no banco? " 5 ... 4 ..." Já estou lá, prestes a abrir a porta. Eu não sou um ladrão de banco, nem mesmo só para jogar, ok? Será que o pessoal que está me vigiando vai rir de mim se não entrar? Sou o autor da minha própria história ou é Blast Theory, e o que vou fazer? Para não me comprometer, e nem estragar o final de A Machine to See With, não vou revelar o que acontece depois.

Este exemplo parece particularmente significativo para investigar a imersão ficcional e os limites do jogo. Podemos contestar pelo menos três das condições tidas como necessárias para imersão ficcional estabelecidas por J.-M. Schaeffer: 1) não ocorre uma reversão na relação habitual entre imaginação e percepção; 2) o estado do sujeito não é apenas retroativo, mas ao mesmo tempo ativo e projetivo; 3) o investimento emocional e afetivo existe, mas ele é voltado principalmente aos limites do jogo e do risco de contaminação entre jogo e realidade ${ }^{25}$. Existe porem, um estado cindido do sujeito ${ }^{26}$, mas ao invés de ser constitutivo à ficção, esse estado torna-se fonte de incertezas, de inquietudes e de ansiedade.

Antes de mais nada, o projeto A Machine to See With questiona a delimitação do famoso circulo mágico de Huizinga. Compreendemos e insistimos bastante sobre o fato de que a obra de Blast Theory desafia constantemente a fronteira entre jogo e vida real. Roger Caillois, no seu livro Les jeux et les hommes ${ }^{27}$ propõe uma definição próxima a esta de Huizinga: "O jogo é essencialmente uma ocupação separada, cuidadosamente isoladas do resto da vida, que geralmente se realiza dentro de limites precisos de tempo e de lugar". No entanto, um terceiro aspecto na definição do jogo sugerida por Caillois mantém seu pleno significado: o curso do jogo não pode ser previsto com antecedência, o resultado deve permanecer imprevisível. O jogador deve preservar a possibilidade de inventar. Porem neste caso, a iniciativa do jogador causa preocupações, pois ele não sabe mais o que exatamente pertence ao jogo, e nem o que lhe pertence enquanto jogador. Finalmente, a única liberdade que lhe é concedida parece ser a decisão de continuar de jogar ou de parar.

c) Ulrike and Eamon Compliant

Ulrike e Eamon Compliant é um projeto que foi apresentado na Bienal de Veneza

\footnotetext{
${ }^{25}$ No original lê-se hors-jeu, termo que compreende aquilo que se situa fora do jogo (N. do T.).

${ }^{26} \mathrm{O}$ estado do autor ou do leitor de ficção segundo J.-M. Schaeffer é decisivamente um estado cindido entre a imersão ficcional e a consciência representacional.

${ }^{27}$ Publicado em português como o titulo Os jogos e os homens: a mascara e a vertigem. Éd. Cotovia, Lisboa, 1990.
} 
em 2009. Trata-se de uma caminhada pela cidade, onde os participantes desempenham os papeis de Ulrike Meinhof e Eamon Collins. A realização do projeto termina com a entrevista de cada participante numa igreja anônima. Ulrike Meinhof foi uma jornalista que participou da liderança do Exército Vermelho na Alemanha Ocidental no início dos anos 70. Ela organizou uma série de roubos e de atentados, antes de ser presa em 1972. Ela cometeu suicídio na prisão em 1976. Eamon Collins tornou-se membro do Exército irlandês em Armagh no final dos anos 70. Responsável pela segurança do IRA, e preso em seguida, se retratou, após ter dado diversos depoimentos contra o IRA. Foi assassinado em 1999.

Blast Theory: "Neste projeto particularmente, jogamos muito forte com a subjetividade. O participante devia escolher ser Ulrike ou Eamon, e depois dessa escolha, ele é (realmente) considerado como tal nos próximos 30/35 minutos de caminhada pela cidade. Em seguida, chegando ao local da entrevista, a primeira pergunta que lhe é feita é: Por que você luta? Neste momento, a incerteza consiste em saber se o participante vai responder sendo ele mesmo no mundo real, aqui e agora, ou a resposta será dada em relação à história que acaba de viver, sendo a de seu álter ego ficcional. Há vários níveis de incerteza no âmbito desta realização: entre sujeito e sua projeção como personagem no jogo; entre o sujeito e Ulrike ou Eamon; entre Veneza, Irlanda do Norte e Alemanha Ocidental; entre o momento presente e o inicio dessa realização; entre um jogo, uma caminhada, uma peça de teatro, um documentário, uma entrevista, um teste de personalidade e o dilema sobre a escolha de um meio de transporte $(. . .)^{28}$."

\section{d) Observações sobre os três dispositivos}

Em todos os dispositivos desenvolvidos por Blast Theory (como em todos os dispositivos de realidades alternadas) 'agir' e 'localizar-se' são primeiramente e fundamentalmente atos que representam o sujeito. No caso do projeto Can You See Me Now, esses atos operam uma tensão entre o mundo real e virtual, que é percebida também na competição entre os dois grupos de jogadores. De forma geral, o projeto procura trabalhar as questões da memória, e da recomposição do público e do privado, que resultam do uso de telefones celulares e de novas ferramentas de virtualização. Enquanto isso, no projeto A Machine to See With, o sujeito encontra-se no centro de uma maquina de visão, que volta sempre nele, e cuja operacionalidade em quanto sistema é crucial. Tomar decisões e questionar os limites do jogo acrescentam neste caso, às primeiras representações do sujeito, outras mais incertas, mas também mais conscientes e mais vivas.

Por outro lado, o dilema ético no âmbito do projeto Ulrike et Eamon Compliant, é também particularmente interessante, pois ele reside na intersecção entre a ficção e a vida real. Torna-se claro que o envolvimento imersivo nessa experiência não exclui um posicionamento critico e reflexivo dos participantes, muito pelo contrário. Tem-se uma consciência desperta do andamento geral do jogo, e, em alguns casos até uma consciência aguda das sobreposições e das interligações entre os mundos real, virtual e ficcional. Essa consciência do jogo e da sobreposição dos três mundos é

\footnotetext{
${ }^{28}$ Matt Adams (Blast Theory). "Compte rendu de la conférence de Matt Adams", Simpósio Fictions immersions et univers virtuels, 27, 28, 29 avril 2011, Université de Paris 1/ UQAM, Université de Montréal, sous la dir. de B. Guelton, R. Bourassa, B. Gervais. (Tradução do autor), Obra a ser publicada.
} 
bastante original, e o pensamento reflexivo que a acompanha determina a configuração artística dos dispositivos elaborados pelo grupo Blast Theory.

\section{Conclusão da primeira parte: por uma abordagem perceptiva e dinâmica do espaço}

A noção de espaço é ainda mais polissêmica e complexa do que a de ficção. Existem provavelmente tantas concepções de espaço quantas abordagens e perspectivas forem possíveis no nosso mundo. Consideremos está definição do vocabulário estético de Etienne Souriau: "Extensão na qual pontos distintos podem existir simultaneamente, constituindo um quadro onde se situam fenômenos materiais e fenômenos físicos."29. Essa definição deixa de lado dois pontos fundamentais que são a percepção e a representação do espaço. Suponhamos que o espaço é apenas um dado natural e independente das nossas representações. Trata-se, portanto, de concebê-lo essencialmente em sua dimensão sensível e perceptível, como uma experiência física e corporal. Mas, a própria percepção não poderá ser pensada como uma atividade meramente receptiva, ou de tratamento das informações que nos cercam. A percepção é uma atividade essencialmente dinâmica, que articula a posição do corpo em relação aos objetos, os trajetos e as ações orientadas do sujeito. Esta atividade dinâmica e construtiva requer representações internas para cada um desses níveis, e de suas articulações.

Duas citações permitem enfatizar melhor a ideia de que a ação é fundamental na constituição do espaço do sujeito, assim como na coordenação dos diversos sistemas cognitivos:

1) Construção do espaço pela ação: Do ponto de vista filosófico, o espaço pode ser pensado como uma questão: por um lado, ele é constituído pelas nossas ações, pelo que fazemos, mas por outro lado, nos temos noção do que podemos fazer, somente fazendo...Esse impulso da ação que desconhece o espaço, faz com que o espaço se torne algo a ser explorado constantemente; sempre mais do que poderíamos conhecer, mesmo se sua existência se dê somente em razão de nossas ações lançadas no desconhecido ${ }^{30}$.

2) Cognição incorporada e estendida: As constatações sobre a expansão do cérebro para a compreensão da totalidade do corpo (cognição incorporada), em seguida, além do corpo aos artefatos (cognição estendida), ou as mentes de outros (cognição compartilhada), e o reconhecimento da importância do ambiente imediato no despertar e ao longo dos processos cognitivos (cognição situada) revolucionaram a abordagem dos fenômenos cognitivos, que não podem mais ser tratados isoladamente ${ }^{31}$.

Em Fictional Minds, Alan Palmer ${ }^{32}$ insiste sobre o fato que as mentes de ficção são intrinsecamente ligadas a apresentação das ações. Neste sentido, a simulação mental situa-se na intersecção do comportamento comum no espaço ambiental (caracterizado pela memória e pelo plano de ação) e da experiência do espaço na fic-

\footnotetext{
${ }^{29}$ Vocabulaire d'esthétique d'Étienne Souriau, publicado sob a direção de Anne Souriau, 3 edição, Paris, PUF, 2010. p. 720.

30 Charles Lenay. "Constitution de l'espace et immersion”, Arob@se, disponível em www.univ-rouen.fr/arobase, volume 1, pp. 85-93, 2005.

${ }^{31}$ Anne Reboul. Resumo da sua comunicação na Sorbonne, em 4 de abril de 2012.

${ }^{32}$ Alan Palmer, Fictional Minds. University of Nebraska Press, 2004, p. 210.
} 
ção tradicional. Assim, a questão da simulação mental é fundamental, porque ela relaciona a memória das ações feitas com as ações a serem realizadas, incluindo as suposições implícitas. Quando as suposições são projetas na trama temporal, sendo construídas e compartilhadas com alguém, elas relevam elementos ficcionais.

\section{Objetivos e evolução da linha de pesquisa Fictions \& Interactions}

Essas considerações sobre as imersões e os espaços envolvidos constituem desenvolvimentos importantes da linha de pesquisa intitulada Fictions \& Interactions. Em seguida farei um breve delineamento de suas trajetórias.

\section{A. Objetivos da linha de pesquisa}

A linha de pesquisa Fictions \& Interactions foi iniciada com um primeiro simpósio internacional realizado em novembro de 2006, intitulado Les arts visuels, le web et la fiction (As artes visuais, a web e a ficção). O objetivo geral desta linha de pesquisa é de promover uma analise sobre as relações entre obras artísticas e ficção. Se a noção de ficção é amplamente explorada no campo da literatura e da filosofia, a questão das obras artísticas, mesmo frequentemente evocada, nunca foi realmente estudada (exceto no caso notável do trabalho de Kendall Walton) ${ }^{33}$.

Esta linha de pesquisa tem como aspiração investigar as características da ficção do ponto de vista das práticas artísticas e visuais. Os dispositivos audiovisuais, as modalidades de exposição, os trabalhos on-line, entre outros, constituem nossos territórios preferenciais de reflexão. Por meio deles trazemos à tona a questão da ficcionalidade da obra de arte contemporânea. O conceito de 'interação' é entendido a partir de uma tripla perspectiva: - Interação entre as mídias numa obra, ou seja 'intermidialidade'; - Interação entre o autor, a obra e o usuário, ou seja 'interatividade'; e, - Interação entre a ficção e a realidade, ou seja, 'interpenetração'.

1) A interação entre as mídias numa obra, designada pelo termo 'intermidialidade', procura estudar as relações entre diferentes suportes e meios semióticos num trabalho artístico. Essas particularidades são analisadas também em relação aos modos de construção das ficções artísticas e visuais.

2) Chama-se de 'interatividade' a interação entre o autor, a obra e o usuário. Nas práticas artísticas recentes (como na arte computacional), as exposições de obras visuais realizadas por meio de dispositivos audiovisuais, performativos e virtuais, e, a interação pensada como forma de imersão ou de distanciamento, redefinem a situação clássica autor-obra-usuário. A interatividade designa a situação clássica de interação entre o artista, a obra, o usuário, como também as situações de fruição da obra via aparelhos tecnológicos e computadores conectados em rede.

3) Sob o termo 'interpenetração' entende-se a interação entre ficção e realidade. Além dos dispositivos interativos (cognitivos ou de aparelhagem) trata-se de estudar

\footnotetext{
${ }^{33}$ Kendall Walton. Mimesis as Make-Believe: on the foundations of the representational arts. Cambridge, Mass.: Harvard University Press, 1990.
} 
as ficções artísticas que procuram (mais ou menos) voluntariamente contaminar ou confundir as relações entre ficção e realidade. Portanto, nosso interesse é focado em obras, cuja estrutura ou finalidade é de questionar a essência e os limites de sua própria ficcionalidade.

\section{B. Evolução da linha de pesquisa}

Podemos tentar uma avaliação dos avanços da nossa linha de pesquisa segundo as trajetórias citadas, como também, retomando as tensões próprias do conceito genérico de ficção. De fato, a definição de ficção não exige uma interação direta com o ambiente onde ela se desenvolve, mesmo se de alguma ou de outra forma ela envolva certas interações que definimos como indiretas. Num primeiro momento, indireto indica o rearranjo dos elementos do mundo comum, usados com uma certa liberdade no mundo ficcional. E, num segundo momento, indireto se refere à ideia de que num universo ficcional é possível modelizar situações inexistentes, que numa perspectiva temporal são suscetíveis de alterar as crenças dos consumidores dessa ficção, ou seja, de um indivíduo ou de uma comunidade. A noção de interação coloca em questão justamente esta natureza indireta da ficção, desafiando suas definições clássicas, assim como seu estatuto. Ela é fundamental para as ficções artísticas, pois ela supõe uma materialização e uma relação concreta com o mundo, incomparáveis com a ficção literária, ou com os mundos possíveis na filosofia.

Um breve histórico dos nossos avanços pode ser elaborado a partir de quatro tipos de eventos: mesas-redondas, seminários, publicações e exposições. Naturalmente, nossa pesquisa foi iniciada com uma série de mesas-redondas que tratavam da noção de ficção artística e suas possíveis definições. Abordando a noção central de suposição ${ }^{34}$, detectamos e exploramos três outras noções de importância primordial: a imaginação, a modelização, a invenção. Foram desenvolvidas e discutidas diversas experiências artísticas, relacionadas aos quatro conceitos citados (a suposição, a imaginação, a modelização e a invenção) $)^{35}$. As interligações entre esses quatro conceitos constituem um campo rico de possibilidades para reflexões teóricas e para experimentações artísticas.

\section{Intermidialidade}

O conceito de intermidialidade foi abordado em 2009, com o simpósio Images dans le récit, récits dans l'image, la fiction à l'épreuve de l'intermédialité (Imagens nos relato, relatos na imagem, a ficção desafiada pela intermidialidade). Tendo em vista as intervenções e as propostas escritas, as questões tratadas neste simpósio constituíram três níveis distintos. O primeiro diz respeito ao problema geral da interpretação. O segundo questiona a interpretação de uma mídia (imagem ou texto, por exemplo), e as suas possíveis confrontações. Finalmente, o terceiro nível leva em consideração especificamente a ficção.

A questão da intermidialidade também está presente no livro Fictions \& médias, intermédialités dans les fictions artistiques (Ficções e mídias, intermidialidade nas fic-

\footnotetext{
${ }^{34}$ A partir dos trabalhos de A. Reboul (2008) e J. Dokic (2009).

${ }^{35}$ A partir dos trabalhos artísticos de Tampon-Lajariette ; Beauregard (2010) e Toma, Lallemand, Sabatier (2009).
} 
ções artísticas) publicado pela editora da Sorbonne, em dezembro de 2011. Nesse volume, as contribuições de Marie-Laure Ryan, Lorenzo Menoud, Bernard Guelton, Karim Charredib, Sandrine Morsillo e Anne Reboul trouxeram estudos de obras artísticas, e esclareceram as bases teóricas usadas na sua análise. A contribuição de Marie-Laure Ryan permite enquadrar e colocar em perspectiva as abordagens da ficção a partir de uma base conceitual clara, relevante e concisa, que se mostrou essencial. Essa base lhe permitiu se concentrar na questão do cinema e da imagem fixa (fotografia e pintura). A pesquisadora discute os pontos de vista controversos sobre os diferentes suportes, propondo três categorias de imagens: imagens que são ficcionais, imagens que não são ficcionais, e imagens para as quais essas duas categorias não são significativas do ponto de vista cognitivo. "Todas as mídias apresentam uma área de indeterminação. A importância dessa área varia em função do meio, e é proporcional à sua capacidade de construir verdades ou de contar a histórias." Aprofundando a análise dessa área de indeterminação, considerando-a típica de todas as imagens únicas e fixas, Lorenzo Menoud se posiciona enquanto artista e teórico compondo uma variedade de declarações textuais a propósito de duas fotografias - uma de Josef Koudelka, e outra de Alexandre Rodchenko.

Assim, esta publicação testemunha os primeiros avanços do grupo de pesquisa Fictions \& Interactions, combinando experiências artísticas e estudos teóricos. $\mathrm{Na}$ minha própria contribuição, a relação imagem/texto é estudada em várias obras de objetivos ficcionais: Nicolas Poussin, Jean Le Gac, Christian Boltanski e Sophie Calle (ou em oposição as obras não-ficcionais de Hamish Fulton). Essa relação de intermidialidade também é desenvolvida na relação fotografia/cinema com os trabalhos de Aernout Mik e Jeff Wall. O conjunto dos componentes descritivos e narrativos destes trabalhos são examinados do ponto de vista da ficção, distintos de seus objetivos artísticos propriamente ditos.

Sandrine Morsillo se debruçou sobre a questão central da exposição como ficção artística a partir de vários casos documentados. Os conceitos de 'contrato' ficcional e exposição parecem ser particularmente interessantes para analisar certas manifestações artísticas, como também a relação entre o autor e o receptor de ficção, e o contrato implícito e ficcional entre os dois. As noções de pontos de vista e de imaginação in situ permitiram abordar de maneira produtiva a noção de exposição e suas relações com a ficção. Karim Charredib tentou desvendar, por meio da análise de um filme, os "artifícios de ilusão" próprios dos filmes documentários e de ficção. "Entre a construção ilusória lúdica compartilhada e a mentira, misturando o verdadeiro e o falso verosímil, esse filme apagou as pistas da verdade ao ponto de cair na sua própria armadilha."

Finalmente, além da questão da mídia, Anne Reboul questiona o estatuto do modelo na pintura. Bethsabée ao banho, Saskia e o Minotauro: as intenções de Rembrandt (ou de Picasso) são suficientes para se estabelecer uma diferença entre a representação de uma ficção (Bethsabée, Minotauro) e um retrato (Saskia)?

A questão central é saber se toda representação de ficção envolve dois níveis de verossimilhança, ou de fato a situação é mais simples do que sugere a teoria da verossimilhança. Distinguindo a 'ficção da mídia', a 'ficção do conteúdo' e a 'ficção do modelo', Anne Reboul propõe uma teoria da ficção baseada mais no conceito de suposição, do que no conceito de verossimilhança. 


\section{Interatividade}

A interação entre o autor, a obra e o usuário - a interatividade - é um tema rico e complexo, que é diretamente ligado ao terceiro eixo de reflexão intitulado interpenetração, precisamente em razão da temática recorrente de imersão. Os pontos de referência propostos no primeiro simpósio sobre os tipos de imersão especificam diferentes territórios para pensar a interatividade: as realidades mistas e aumentadas, a imersão vídeo-lúdica, as configurações artísticas e performativas. O enquadramento e as perspectivas teóricas desses seminários sobre os tipos de imersão exigem definições mais aprofundadas. Por exemplo: uma melhor distinção entre imersão ficcional e virtual em obras artísticas ou de maneira geral, uma distinção mais objetiva e segmentada entre os universos virtual e ficcional, ou, ainda, a questão das entradas e das saídas nos três tipos de imersão real, ficcional, e virtual. O estudo da imersão em situação real, relativamente óbvio e intuitivo (imersão emocional, urbana, linguística, etc.) permaneceu quase inexplorado. No entanto, a pesquisa sobre os tipos de imersão permitiu esclarecer distinções férteis entre a imersão, como constituição material de um dispositivo imersivo e a presença e os efeitos de presença, entendidos como uma experiência subjetiva, e dependente da motivação do individuo.

\section{Interpenetração}

No caso do terceiro eixo chamado Interpenetração - dedicado à indefinição e/ ou à perda de fronteiras entre ficção e realidade - as pesquisas sobre a imersão forneceram um campo privilegiado de reflexão. A questão das realidades mistas nos jogos de realidade alternada constituiu um campo fértil para analisar a interpenetração entre mundo real, virtual, e, numa medida menor, ficcional. As intenções de uma boa parte das obras de Blast Theory são claramente investigar os limites e as fronteiras do jogo e do quadro ficcional. Contudo, pesquisas mais frequentes sobre a imersão em exposições de arte permitiram detectar situações inovadoras nas quais interagem a experiência do sujeito, a representação midiática e o contexto concreto da experiência imersiva. As abordagens da imersão do ponto de vista da percepção e da fisiologia da ação mostraram-se bastante interessantes, e merecem ser exploradas com mais atenção e integradas nos experimentos artísticos. Elas permitem visar um quadro teórico e experimental para futuros desenvolvimentos a cerca das relações entre exploração e construção de espaços relacionados com as ficções artísticas.

O diagrama abaixo tenta resumir os avanços e os movimentos das pesquisas realizadas. $\mathrm{O}$ conceito de jogo surgiu como central na conferência inaugural da linha de pesquisa, ele se encontra subjacente a cada etapa nesse diagrama, como também no contexto da noção de imersão. Ele é ao mesmo tempo próprio ao conceito de ficção e exemplar das experimentações relacionadas com as ficções artísticas. 


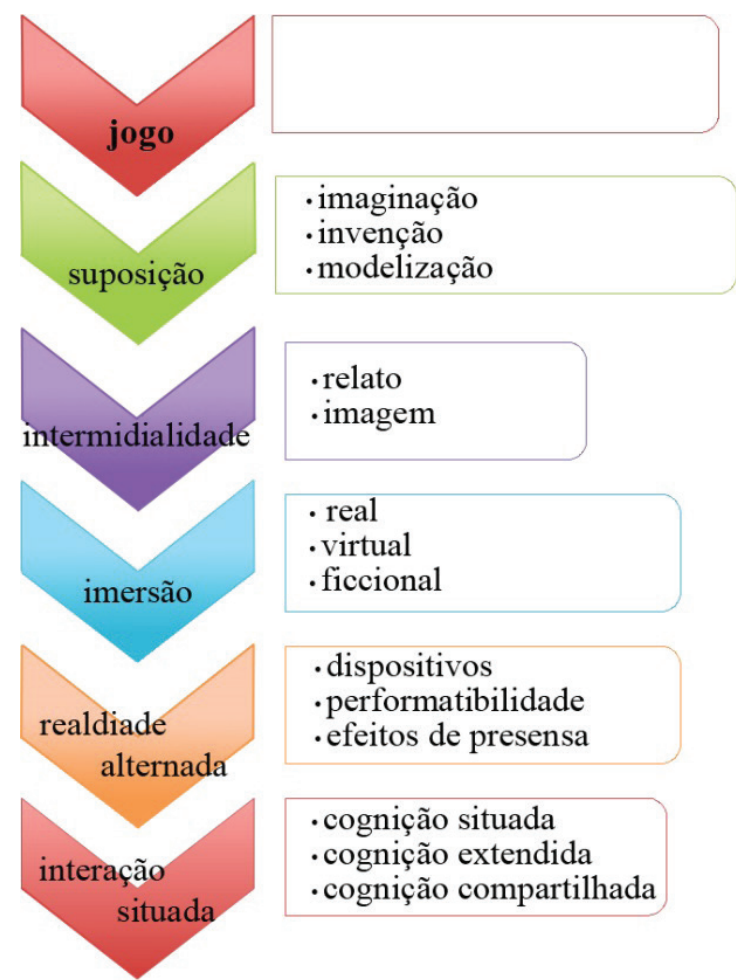

Figura 1 - O diagrama dos avanços e movimentos das pesquisas realizadas.

\section{Constituição de espaços}

Assim, por meio das reflexões do grupo de pesquisa Fictions \& Interactions, a questão do jogo se confirmou como conceito-chave para pensar a ficção (Hill, 2007; Caira, 2011), como também para analisar as experimentações artísticas contemporâneas. As realidades alternadas concebidas geralmente como jogos urbanos, podem ser pensadas de forma mais ampla, nas propostas artísticas que recorrem ao uso de vários espaços. ${ }^{36}$ Identificar melhor os espaços que estão em jogo e suas interações surge como uma perspectiva interessante após a exploração de diversas situações imersivas em contextos de realidade alternada. Consideramos como um dado posto o papel central da ação na construção do espaço do sujeito (Poincaré, 1907; Berthoz, 1997; Jeannerod, 2002).

Contudo a interação sensório-motora com o ambiente exige o desenvolvimento de representações internas do sujeito. Essas representações constituem as interfaces entre o conhecimento adquirido do espaço ambiental que nos cerca (memória de curto ou longo prazo) e os planos de ação que permitem ao sujeito projetar suas ações no futuro. Assim, os espaços do sujeito são pensados por meio de duas modalidades básicas, que são sua ação no ambiente e a simulação mental. Elas permitem memorizar os percursos no espaço, como também projetar um plano de ação.

O conceito de plano de ação é fundamental na compreensão da relação do su-

\footnotetext{
${ }^{36}$ A noção de pluralidade dos espaços, evidentemente a ser explicitada diante pelo menos duas considerações: 1) o impreciso, o aspecto múltiplo até mesmo contraditório da noção de espaço e 2) a constatação que nenhuma obra artística revela a uma primeira vista uma pluralidade de espaços.
} 
jeito com o espaço e seu posicionamento nele, como também de forma geral, de sua identidade (Proust). ${ }^{37} \mathrm{~A}$ simulação mental situa-se na interseção do comportamento normal no espaço ambiente (memória, plano de ação) e da experiência do espaço na ficção tradicional. A questão da simulação mental deve ser explorada plenamente, quando se trata de ficções artísticas, pois essas últimas envolvem o corpo e o movimento do sujeito no espaço de forma inédita e incomparável com as ficções tradicionais (literatura, cinema).

Entender melhor a simulação mental, sua função instrumental e operacional, juntamente aos fatores provenientes da suposição ou da imaginação, é um assunto de pesquisa fecundo e pouco explorado. Mas esta questão particular deve antes, ser estudada dentro da arquitetura do conjunto das interações entre os espaços da obra e os espaços do sujeito, que são a base das relações entre ficção e espaço.

21 de abril de 2012

\section{Referencias}

Aumont, J., Bergala, A., Marie, M. \& Vernet, M. Esthétique du film. Éd. Nathan, Paris, 1983.

Gombrich, E. H. L'art et l'illusion. 1960, Éd. Gallimard, Paris, 1987.

Grumbach, A., Cognition virtuelle, réflexion sur le virtuel, ses implications cognitives, ses réalisations artistiques. GET / ENST Paris, 2004.

Lenay, Ch. «Constitution de l'espace et immersion », Arob@se, www. www.univ-rouen.fr/arobase, volume $1,2005$.

Metz, C. Le signifiant imaginaire : psychanalyse et cinéma. Éd. UGE, coll. « 10/18 », Paris,1977.

Montalbetti, Ch. La fiction. Éd. GF Flammarion, Paris, 2001.

Palmer, A. Fictional minds. University of Nebraska Press, 2004,

Proust, J. « Identité », in Vocabulaire des sciences cognitives. Olivier Houdè (dir.), PUF, Paris, 1998.

Ryan, M.-L. Space, place and story: Toward a spatial theory of narrative. Projet d'ouvrage collectif, 2011.

Ryan, M.-L. « Fiction, cognition et médias non verbaux », in : Fictions \& médias, intermédialités dans les fictions artistiques. Bernard Guelton (dir.), Publications de la Sorbonne, Paris, 2011.

Ryan, M.-L. Narrative as virtual reality: immersion and interactivity in literature and electronic media. Johns Hopkins University Press, Baltimore, 2001.

Schaeffer, J.-M. Pourquoi la fiction ? Éd. Seuil, Paris, 1999.

37 Joëlle Proust, "Identité", in : Vocabulaire des sciences cognitives, Olivier Houdè (dir.), PUF, Paris, 1998. 
Schaeffer, J.-M. « Quelles vérités pour quelles fictions ? », in Vérités de la fiction. L’Homme, 2005.

Souriau, A. Vocabulaire d'esthétique. PUF, Paris, 2010.

Wollheim, R. «La représentation iconique », in : Esthétique contemporaine, art, représentation et fiction. Textes réunis par J.- P. Cometti, J. Morizot, R. Pouivet, Éd. Vrin, Paris, 2005. 